画像処理による摩摖圧接部の形状認識

1.はじめに

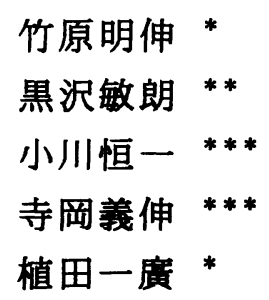

摩擦圧接継手の製作過程において生成されるバリの形状をパソコンを用いた画像処理 システムで測定し、その值によって継手性能を評価することを試みた。従来、摩擦圧接 継手は破壊試験によりその強度なとの性能評価が行われてきたか、この方法は多大の時 間と費用がかかり、また工程内検査や全数検査には適していない。超音波などを用いた 非破壊試験の適用が検討されつつあるが、完全な実用化には至っていない。

本研究では、このような背累をもとに、摩擦圧接中に生成されるバリの形状を認識す ることによって継手性能を評価することを試みた。すなわち、バリの形状は圧力、回転 数、摩擦時間なとの压接条件によって変化するが、適切な厌接条件で生成されるバリの 形状が認識でれれ、バリの形状から逆に最適压接条件を選定でき、しかも継手性能を 推測できる。従来、厌接された状態でバリの形状を測定することはなされなかった。そ こで、普及しつつあるC C D カメラで撮像し、パーソナルコンピュータでその画像デー 夕を処理する方法を検討した。その結果、良好な結果を得ることができた。

\title{
2. 摩擦圧接法と継手強度試験法
}

摩擦圧接機は加圧系、および回転系から成り立つている。压接は静止側母材を回転側 母材に押し付けて摩擦させると、摩擦熱が発生して摩擦面が変形してバリを生成するが、 その過程で適当な接合状態になったとき、回転を停止させて完了する。用いた母材は、 A5056アルミニウム合金である。压接条件である主要な 4 つの压接因子（摩擦压力 $\mathrm{P}$ 、、 アフセセット圧力 $\mathrm{P}_{2}$ 、摩擦時間 $\mathrm{t}$ 、、回転数 $\mathrm{N}$ ) の組み合わせで摩摖圧接を行った。なお、 継手性能は引張強さ $\sigma_{\text {в }}$ とし引張試験で求めた。

3. バリの形状の測定法

3. 1 バリの形状測定装置の構成

バリ形状測定装置は画像入力装置（CＣDカメラ）と画像処理装置（パーソナルコン ヒュータ、画像ボード) から構成される。C C D カラによって撮像された空間画像は、 N T S C 方式のアナログ信号として得られる。このアナログ信号は、画像ボードのA／ D変換部で256諧調のデジタル值に変換され（量子化）、フレームメモリーに取り込まれ
* 大阪短期大学
** 摂南大学
*** 大阪府立大学 
る。この解像度は640x480画素である。 原画像を図 1 に示す。

4. 標本化画像の加工

4. 1 画像の標本化

画像入力装置より入力される画像空 間から原画像を $640 \times 400$ 画素の256階調 で取り込んだ。アナログ信号を $\mathrm{A} / \mathrm{D}$ 変 換して得られた量子化デー夕は雑音を 含むのでメディアン・フィルターをか け雑音除去を行い、さらに400x400画 素に切り出しを行った。

\section{22 值化処理}

対象となる測定物の形状と背景 との輝度差を調べるため、輝度七 ストグラムを求めた（図 2 )。こ れより、境界の輝度 (閥值) を84 と設定した。原画像の中から測定 対象の形状を抜き出す処理として、 2 値化処理を行った。

$$
g(x, y)= \begin{cases}1 & f(x, y) \geqq t \\ 0 & f(x, y)<t\end{cases}
$$

ただし、t:閾値

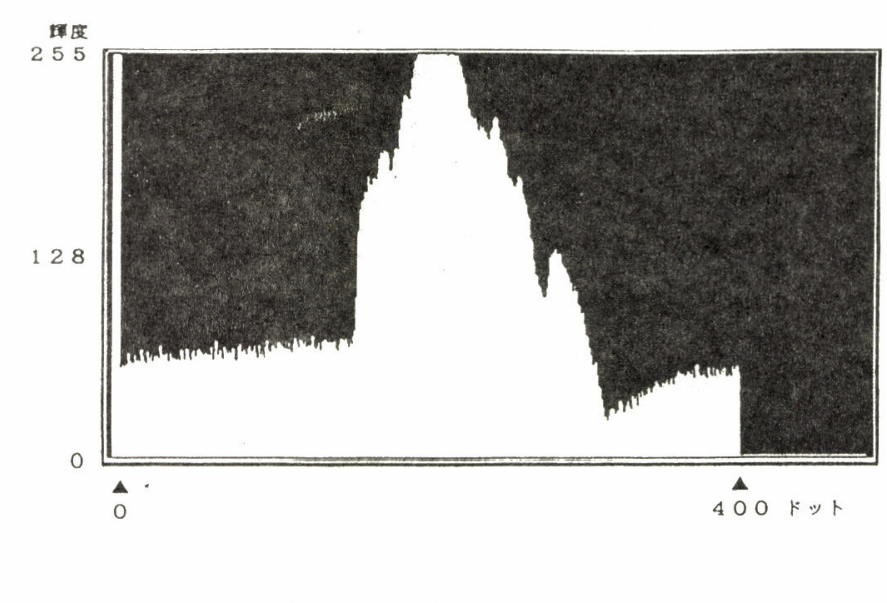

図2。輝度ヒストグラム

\section{3 輪郭抽出}

輪郭線の抽出方法として、輪郭 線追跡処理を用いた。輪郭線追跡 処理は原点より垂直方向に走查し、 外周輪郭線に達した点から時計回 りに探索を行って求めた（図 3 )。

4. 4 母材外周輪郭線の水平化 取り込まれた原画像は水平に設 置されているわけではない。以後 の計算処理を簡単化するため外周 輪郭線が水平になるように幾何学

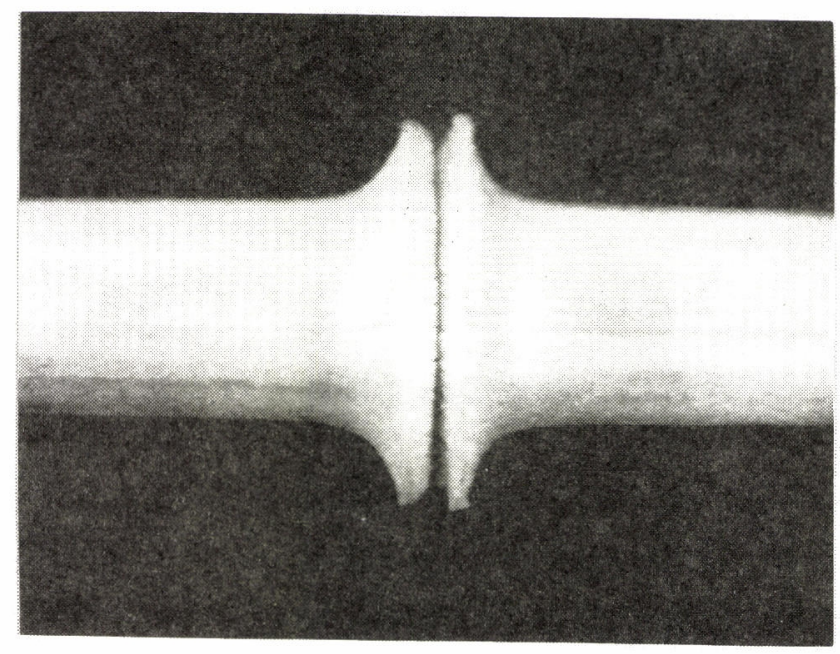

図 1 . 原画像 
的変換処理を行った。そのためにアフィン変換を用いた。この方法は次の式による。

$$
t_{\mathrm{r}}(\mathrm{x}, \mathrm{y})=\left[\begin{array}{cc}
\cos \theta & -\sin \theta \\
\sin \theta & \cos \theta
\end{array}\right]\left[\begin{array}{l}
\mathrm{x}_{0} \\
\mathrm{y}_{0}
\end{array}\right]
$$

ただ、 $\theta=\tan ^{-1} \mathrm{~g} 、 \mathrm{~g}$ :傾き

さらに、最近傍法で補間を行った。得られた外周輪郭線を図 4 に示す。

4. 5 バリの高さの測定

バリの高さは、原点より水平

に走查を開始し、最初に到達し

た点をとった。

4.6 止端部の定義と測定

バリの始点は、母材輸郭線か

ら外側に変形を開始した点とし

（立ち上がり点）、この部位を 止端部と呼ふっ。この位置を厳密

に測定することは困難である。

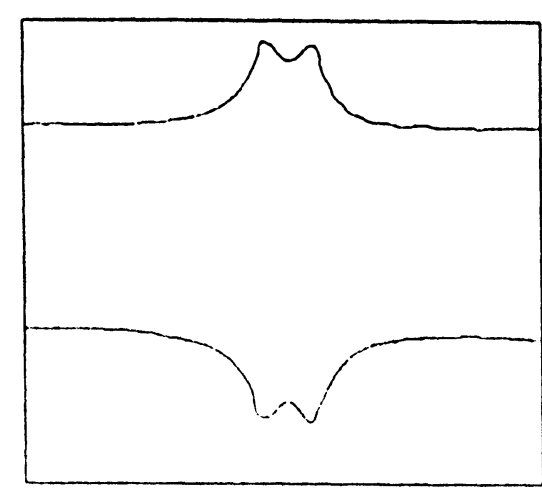

困 4. 外周輸郭線 ここでは、罒 5 に示すように変 移した画素より 2 次関数に近似 して求めた。

$$
\begin{aligned}
& \mathrm{y}=\mathrm{a}\left(\mathrm{x}-\mathrm{Q}_{0}\right)^{2} \text { より、} \\
& \mathrm{Q}_{0}=\mathrm{x}_{2} /(1+\sqrt{2})
\end{aligned}
$$

次に、止端角は量子化空間におい ては偏角として次のように求められ る。

$$
\theta=\mathrm{tan}^{-1}\left(1 / \mathrm{Q}_{0}\right)
$$

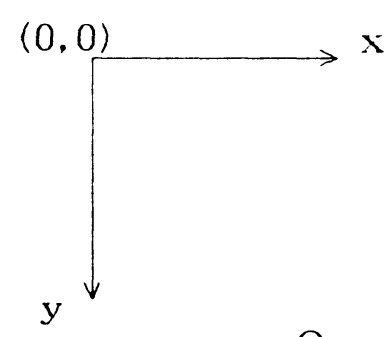

Q॰
Q2

$\rightarrow \square$

4. 7 バリの幅の測定

バリの幅は、左立ち上がり点と右立ち上がり点の間隔長として求めた。

4. 8 バリの断面積の測定

バリの断面は、左立ち上がり点と右立ち上がり点を結んだ直線より上部のバリの外周 
輪郭線までのドットを計上したものとして、次の式により得られる。

$$
\mathrm{S}=\mathrm{D}_{\mathrm{d}}{ }^{2} \times \mathrm{D}
$$

ただし、S : 面積 $\left(\mathrm{m} \mathrm{m}^{2}\right)$

$\mathrm{D}_{\mathrm{d}}: 1$ ドット当たりの精度 $(\mathrm{mm})$

$\mathrm{D}$ ：累計ドット数

5. 画像抽出データと継手性能の関係

画像処理によって得られ た測定値と圧接結果を相関 分析法で検討した。引張強 さと各形状因子との単相関 分析表を表 1 に示す。また、 各因子の組み合わせによる 重相関分析を行った結果、 バリの幅とバリの高さによ る組み合わせ因子を用いた 方がより摩擦压接継手の性 能評価には有効であること 表 1 単相関分析表

\begin{tabular}{|c|c|c|c|c|c|c|}
\hline & 倍H & 槙故 $/ \mathrm{H}$ & رイリ断面相 & 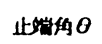 & 曲炏怪 & 引|张さ \\
\hline 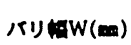 & 0.20 & 0.82 & 0.11 & 0.03 & 0.15 & 0.01 \\
\hline ) & - & 0.55 & 0.81 & 0.00 & 0.12 & 0.73 \\
\hline 此 $\mathrm{W} / \mathrm{H}$ & - & - & 0.42 & 0.01 & 0.04 & 0.24 \\
\hline 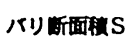 & - & - & - & 0.08 & 0.23 & 0.71 \\
\hline 此角 $\theta$ & - & - & - & - & 0.18 & 0.00 \\
\hline 曲半坢 R & - & - & - & - & - & 0.18 \\
\hline
\end{tabular}
が明らかとなった。次に、 回帰分析で得られた回帰式 を示す。

$$
\begin{aligned}
& \sigma_{\text {в }}=-40.14+5.35 \mathrm{~W}+42.86 \mathrm{H} \\
& \text { ここで、 } \sigma_{\mathrm{B}} \text { : 継手の引張強さ } \quad(\mathrm{MP} \mathrm{a}) \\
& \mathrm{W} \text { : バリ幅 ( } \quad(\mathrm{mm}) \\
& \mathrm{H} \quad \text { ：バリ高 ( } \mathrm{mm} \text { ) }
\end{aligned}
$$

\section{6.おわりに}

本研究においては、王接後に生成されたバリの形状の特徵を画像処理によって数值化 する方法を検討し、さらに、数值化データで継手性能をおおよそ推測し得ることを確か めた。

\section{参考文献}

1）小川恒一：摩擦圧接協会研究発表会資料、163，(1980).

2 ) 小川恒一、山口博、坂口一彦、: 溶接学会全国大会講論集、No. 53, (1993).

3）日本図学会編：CGハンドブック、森北出版、(1989).

4 ）長谷川順一、興水大和、中山晶、横井茂樹：画像処理の基本技法、技術評論社、 (1986). 